\title{
Professor Dorota Filipczak In Memoriam
}

The plan had been that we would meet in Autumn 2020 at the biennial conference of the International Society for Religion, Literature and Culture $^{1}$ in Chester, close to the English/Welsh border. I was excited because Dorota had promised to present a paper on Ariana Grande and her 2018 music video, "God Is a Woman."

Of course, the conference was then postponed because of COVID-19, and, sadly, we never met in person again. And yet, as an academic, she has given me the means to "keep company" with her, through memories of course but also, wonderfully, through her scholarly publications. In 2019, when we first spoke about Ariana Grande, Dorota was at work on another article for the Text Matters journal ("Made to Connive"), addressing the influence of popular culture on women, adding to her existing work on the theme. She had long been interested in the impact of popular cultural forms and, particularly, the impact of western tropes in post-Soviet Poland. Growing up in Poland under a communist government, she welcomed new possibilities when they came-not least, the personal and professional rewards of building friendship networks and travelling across former boundaries. At the same time, she was also aware of the potential for sexism and misogyny to insinuate their way back into seemingly liberated lives, "now that we are inundated with the icons of American mass culture, and Polish glossies for ladies are marketing the woman as a product" ("Autonomy and Female Spirituality" 213). As she said:

Oppressive gender stereotypes did not disappear with the communist regime. On the contrary, they are alive and well in hundreds of TV advertisements. For instance, there is the ad which shows a smiling,

2 See https://www.youtube.com/watch? $\mathrm{v}=\mathrm{kHLHSlExFis} \mathrm{(2018).}$ 
sexy housewife in the company of the latest scouring powder, while her husband is enjoying his beer in the male camaraderie of a pub. Unfortunately the attitude of the church adds to this image of the new capitalist family. The Catholic church emphasizes the woman's maternal role (generally bypassing men's commitments as fathers) to the lesser or greater exclusion of her political role and intellectual potential. (213)

And whilst the leaders of the Solidarity movement continue to be celebrated in the west as champions of democracy, she commented drily, that, for all that, the movement had given little evidence of solidarity with women's rights.

One reason I was looking forward to hearing Dorota discuss Ariana Grande's music video was that whilst it engaged with the problematic influence of popular culture on women-this very familiar theme in Dorota's work-Ariana Grande's music video itself appeared to take a more positive approach towards women, and especially women of colour, and to the possibilities of expressing themselves as women within a context that, previously, had been so dominated by men and patriarchal values. The paper she was writing for Text Matters, concerning contemporary versions of the fairy tale, Cinderella ("Made to Connive"), was still predominantly focussed on identifying the problems of popular culture. She was drawing on Michèle Le Douff's notion of "regulatory myths" (27) that frame and police female conduct and aspirations. Le Douff had pointed out that Christian myths tended in a general sense to align with "a vague and ponderous prohibition on knowledge" (27). The original sin in western society, she suggested, had always been the sin of wanting to know (28), intensified in the case of women. Dorota's reading of Cinderella was picking up on the regulatory myth-more difficult to see in a "secular" society—of the Virgin Mary ("Made to Connive" 71); the feminine as virginal, unknown and unknowing, and compliant. She drew a connecting line back from princess videos for little girls, to these older but still impactful Christian idealizations of passively consenting, incurious female figures who abrogated their autonomy in favour of an active male principle-with the crystal slipper an all too obvious symbol of her coveted virginity.

At an early stage of this conversation, Dorota had sent me the link to a subversive parody of Kenneth Branagh's 2015 version of the Cinderella story, taking the form of a Russian music video, entitled “Зацепила," directed by Arthur Pirozkhov and Denis Kovalsky. ${ }^{3}$ The video starred Aleksandr

3 See https://www.youtube.com/watch? $=$ XQYNUwYHV1c (2019). Available in English as "Dancing All Through the Night" since March this year: https://www.youtube. $\mathrm{com} /$ watch? $v=$ iLszfjZLg0 (2021). 
Revva (Arthur Pirozkhov's stage name), an actor from what Dorota referred to as "the troubled area of Donetsk claimed by Russia and the Ukraine" (72). (Perhaps, with her interest in marginalized peoples and spaces, this had also attracted her attention.) She told me that the title of the video literally means, in an unambiguously active mood, "She accosted me," but this was later translated into English as "Caught,"4 once again, shifting the focus away from a potentially active-if transgressive-female figure and back onto the male. For Dorota, the Pirozkhov and Kovalsky music video had catalyzed a more general unease about the persistent Disneyfication of key stories within western cultural contexts. It was grist to the mill of her concerns about regulatory myths still infiltrating societies that often boldly claimed to have moved beyond gender injustice. She was disappointed by Kenneth Branagh's efforts, in his 2015 version, to produce something more progressive (75). The sparkling Russian music video, full of wit and mischief, had caught her attention precisely because it so obviously parodied Branagh's "safe" alternative (75). But if it initially seemed to acknowledge the transitory nature of youthful beauty, pushing back against the conventions of fairy tales in a way that might have served the critical feminist viewer, it quickly became obvious that it was drawing its sharpness and sauce from assumptions about women that were scarcely less problematic. When the clock strikes twelve, and the prince kisses his mysterious dancing partner, the alluring young woman suddenly takes on a homely appearance. In the prince's imagination, she and her children become monstrous, eating and drinking gluttonously and laughing immoderately, an enormous weight in a tiny carriage in which the-still handsome-prince is squashed into a corner. As Dorota noted, Le Douff had observed that one way in which the regulatory myth operates is by making certain claims ("women will grow older," "women have a desire for knowledge") appear "vaguely indecent" (27). In a vision clearly intended to evince a response of disgust, the Cinderella figure in the Pirozkhov and Kovalsky video throws the crystal slipper out of the carriage window where it smashes to pieces. In his imagination, however, putting the reassembled slipper back on the woman's foot has the effect of restoring the beautiful illusion. The video then drives a (pumpkin?) coach and horses through any critical sense of reality. To secure or fix this illusion, the prince glues the slippers to his dancing partner's feet and binds them on with bright blue, industrial-grade sticky tape. Dorota sees the attractions of Pirozhkov and Kovalsky's clever twists and their "jubilant" conclusion. We all love to dance and we want to avoid looking "po-faced." As women, particularly, we are so often put down with the claim that we "can't take a joke." But

4 See "Made to Connive" (72). 
she warns us not to be fooled. The truth of the matter is that regulatory myths "relentlessly reassert their sway in patriarchal culture" ("Made to Connive" 75).

We talked a little about whether it might be worth looking at the Princesses of Frozen or some other more recent Disney movies to see how far the Disney corporation-as an important vector of cultural (and gender) values in the west-had shifted, or was attempting to shift, away from egregious gender stereotyping. But Dorota rightly wanted to put her critical efforts into an analysis of Ariana Grande's music video. It was perfect as a case study for investigating popular culture as a possible medium for more woman- and race-positive ideas and values. The video grasped the intersectional issue that it is never just about gender but about overlapping forms of social disadvantage; however, it also tapped into her interest in the powerful patriarchal language, myths and symbols of European Christianity. Ariana Grande's “God Is a Woman” video couldn't be more different to Pirozkhov and Kovalsky's piece. Of course, in looking at the video, Dorota would still need to make a serious and critical point about the deep and persistent effects of popular culture on how women are seen and valued. In her abstract for the conference, she explained that she would use the work of her friend and colleague Pamela Sue Anderson as a key theoretical source or intertext. She would focus her attention on the way in which, in Anderson's Feminist Philosophy of Religion,

[she] draws the readers' attention to Luce Irigaray's comments about the way in which men have a habit of stealing woman's light to illuminate their path. The theft of female potential which is made to serve male needs is exposed by Anderson who seeks to restore reason to women who have been placed on the side of irrationality, desire and death. (Unpublished abstract)

Her main concern would be

to explore the way this particular music video brings together a quotation from Ezekiel 25:17, refracted through its made up version from Tarantino's Pulp Fiction and reinterpreted from a sexually different perspective in the above-mentioned scene, and the famous creation of Adam by Michelangelo on the vault of the Sistine Chapel refigured by Harmonia Rosales and other feminist artists (e.g., in the project called "Sister Chapel"), who set out to reclaim the stolen light of female creativity (Feminist Pbilosophy of Religion 99). (Unpublished abstract)

Although we did not have time to talk about the paper very much, it was clear that Dorota was excited by the prospect of addressing a popular music 
video in which a female figure, and a representation of the divine, presented herself in contrast to the Cinderellas of Disney, Branagh or indeed, Pirozkhov and Denis Kovalsky, as not only beautiful but dynamic, dancing for her own pleasure as much as for that of her audience. In the video, a monumental Grande smashes St Peter's Basilica in Rome-a symbolically significant, and here, an unmistakably patriarchal, structure-with a hammer. The action encompasses a range of forceful possibilities-from an attack on a toxic set of values or beliefs, to the destruction of a "glass ceiling." This is a music video with an authentically feminist message that serves to illustrate what Dorota referred to in her abstract as reclaiming the stolen light of women's creativity. Dorota's feminist work had emerged alongside her critical appreciation of literature and particularly literature created by or within marginalized communities. So it makes sense that she was so interested in an artist whose work has raised questions of gender and race justice to people's attention in a popular idiom, even or perhaps especially given the accusations of cultural appropriation that have sometimes been levelled against Grande. ${ }^{5}$ In this video, "God Is a Woman," Grande's highly provocative references challenged stereotypically white, male and masculine forms of representation that have dominated the visual, as well as the invisible, structures of Christianity from the United States to Eastern Europe for many centuries. And, as feminists have long argued, the metaphors of the masculine, Father "God" of Christianity represent, perhaps, one of the most powerful "regulatory myths" of all time.

It is hard to accept that Dorota will not be presenting this work at the conference in 2022, or starting to move on to new and exciting projects, showing the kind of academic leadership that she has personified for more than thirty years. But her thinking and writing remain; she is still our conversation partner in this sense. Her integrity, insight and courage are still in evidence to warn and encourage and it is wonderful to know that the Music Video project she started in 2020 will be continuing.

\section{Works CiTED}

Anderson, Pamela Sue. A Feminist Philosopby of Religion. Blackwell, 1998. https://doi.org/10.1177/135583589800500910

Filipczak, Dorota. "Autonomy and Female Spirituality in a Polish Context: Divining a Self." Feminist Philosophy of Religion: Critical Readings, edited by Pamela Sue Anderson and Beverley Clack, Routledge, 2004, pp. 210-22.

5 See Kornhaber. 
Filipczak, Dorota. "Made to Connive: Revisioning Cinderella in a Music Video. From Disney to Arthur Pirozkhov: A Case Study.” Text Matters, vol. 10, 2020, pp. 67-78. https://doi.org/10.18778/2083-2931.10.04

Filipczak, Dorota. Unpublished confirmed abstract for the International Society for Religion, Literature and Culture conference Transmutations and Transgressions. 25 Apr. 2020.

Kornhaber, Spencer. "How Ariana Grande Fell Off the CulturalAppropriation Tightrope." The Atlantic, 23 Jan. 2019, https://www. theatlantic.com/entertainment/archive/2019/01/ariana-grandes-7rings-really-cultural-appropriation/580978/, accessed 25 July 2021.

Le Douff, Michèle. The Sex of Knowing. Translated by Kathryn Hamer and Lorraine Code. Routledge, 2003.

Alison Jasper was, until 2019, Senior Lecturer in religion and gender studies in the Faculty of Arts and Humanities at the University of Stirling. She was a co-founder of the MLitt/MSc (applied) programme at Stirling University in Gender Studies: https://www.stir.ac.uk/courses/ pg-taught/communications-media-culture/gender-studies/. She is one of the co-founders of the Critical Religion Association: http://www. criticalreligion.org/. From 2018, she has been an Honarary Research Fellow in the Faculty of Social Sciences at the University of Stirling, participating in a research project, funded by the Scottish Government, concerned with the impact of mentoring interventions on early career teachers.

https://orcid.org/0000-0003-2632-9501

\section{s0ph1a@virginmedia.com}

